\title{
Characterization of the Binding and Internalization of Tetanus Toxin in a Neuroblastoma Hybrid Cell Line
}

\author{
Gregory C. Staub, ${ }^{\star}$ Kevin M. Walton, $\dagger$ Ronald L. Schnaar, $†$ Timothy Nichols, ${ }^{\star}$ \\ Roopa Baichwal, ${ }^{*}$ Kathryn Sandberg, ${ }^{*}$ and Terry B. Rogers* \\ *Department of Biological Chemistry, University of Maryland School of Medicine, Baltimore, Maryland 21201, and \\ †Departments of Pharmacology and Neuroscience, The Johns Hopkins University School of Medicine, Baltimore, \\ Maryland 21205
}

Tetanus toxin is known to bind neuronal tissue selectively. To study the interactions of this potent neurotoxin in an intact cell system, the binding of ${ }^{125}$ I-tetanus toxin was characterized in a neuroblastoma retina hybrid cell line, N18-RE-105. The binding of ${ }^{125}$ I-tetanus toxin to membranes prepared from N18-RE105 cells showed many similarities to the interactions of ${ }^{125} \mathrm{I}$ toxin with rat synaptic membranes. The binding was decreased with increasing temperature, ionic strength, and $\mathrm{pH}$. ${ }^{125} \mathrm{I}$-Toxin bound to membranes with high affinity: $K_{\mathrm{D}}=0.62 \pm 0.05 \mathrm{nM}$; $B_{\max }=196 \pm 45 \mathrm{pmol} / \mathrm{mg}$ protein. Quantitative thin-layer chromatography and acid-degradation analysis revealed that N18RE-105 cells contained polysialogangliosides $G_{1 \mathrm{a}}$ and $G T_{1 \mathrm{~b}}$ in high concentrations. An assay was developed to quantitate surface-bound and internalized ${ }^{125}$ I-tetanus toxin by exploiting the observation that surface-bound ${ }^{125}$ I-toxin is susceptible to pronase digestion. When cells were incubated with ${ }^{125}$ I-tetanus toxin at $0^{\circ} \mathrm{C}$, all of the bound ${ }^{125} \mathrm{I}$-toxin could be degraded with pronase. In contrast, when the incubations were performed at $37^{\circ} \mathrm{C}$, within 10 min about $50 \%$ of the total cell-associated ${ }^{125}$ Itoxin was pronase-resistant. Temperature pulse experiments demonstrated that ${ }^{125}$ I-tetanus toxin that was bound to cells at $0^{\circ} \mathrm{C}$ rapidly disappeared from the surface when the cells were warmed to $37^{\circ} \mathrm{C}$, as revealed by the appearance of pronase-resistant radioactivity. This internalization was sensitive to metabolic inhibitors. Thus, N18-RE-105 cells are one of the few neuroblastoma cell lines that possess a ganglioside pattern similar to that found in normal brain, and they have tetanus binding sites that exhibit properties resembling those described in synaptic membranes. These cells provide an excellent model to study the events that occur in the intoxication process subsequent to initial surface binding interactions.

Tetanus toxin is an extremely potent protein neurotoxin, with lethal doses in the range of $1 \mathrm{ng} / \mathrm{kg}$ in rodents (Habermann, 1973; Mellanby and Green, 1981; Wellhoner, 1982). The toxin's major effect on the CNS is presynaptic and is thought to involve an inhibition of the evoked and spontaneous release of neurotransmitter (Bergey et al., 1983; Collingridge et al., 1980; Curtis and DeGroat, 1968; Davies and Tongroach, 1979). Although

Received July 19, 1985; revised Sept. 18, 1985; accepted Oct. 23, 1985

This work was supported by U.S. Army Medical Research and Development Command Contract DAMD 17-83-C-3114 (T.B.R.) and National Institutes of Health Grant HD 13010 (R.L.S.). K.M.W. was supported by Training Grant GM 07626 from the National Institutes of Health. R.L.S. is a recipient of American Cancer Society Faculty Research Award FRA-280.

Correspondence should be addressed to Dr. Terry B. Rogers, Department of Biological Chemistry, University of Maryland School of Medicine, 660 W. Redwood St., Baltimore, MD 21201 .

Copyright (C) 1986 Society for Neuroscience $0270-6474 / 86 / 051443-09 \$ 02.00 / 0$ very little is known about the molecular mechanism of toxic action, the intoxication process probably involves a number of steps: (1) specific high-affinity binding between the toxin and neuronal cell surface receptors; (2) internalization of the toxin; (3) translocation of the toxin via retrograde intraaxonal as well as transsynaptic transport to its toxic site of action; and finally, (4) specific perturbation of the neurotransmitter release process (Price et al., 1975; Schwab et al., 1979).

It has been known for some time that tetanus toxin is selectively bound by neural tissue (Dimpfel et al., 1977; Habermann et al., 1973). More recently, high-affinity receptors for radiolabeled tetanus toxin, with affinities in the nanomolar range, have been identified and characterized on brain membranes (Goldberg et al., 1981; Lee et al., 1979; Rogers and Snyder, 1981). These reports suggest that the receptor is comprised of complex gangliosides, such as $\mathrm{GD}_{1 \mathrm{~b}}$ and $\mathrm{GT}_{1 \mathrm{~b}}$ (Holmgren et al., 1980; Stoeckel et al., 1977).

In order to directly assess the physiological role of tetanus receptors in the intoxication process, an intact cell system is essential. In the present study we have identified a hybrid cell line (N18-RE-105) of neuronal origin that not only has membranes that contain a pattern of polysialogangliosides similar to those found in mammalian brain, but which also displays a high capacity for tetanus toxin binding. Most reported cell lines do not contain significant amounts of complex gangliosides, nor do they express significant levels of high-affinity tetanus receptors (Dimpfel et al., 1977; Mirsky et al., 1978; Rebel et al., 1980; Yavin and Habig, 1984). The tetanus receptor in the N18-RE105 cells was found to be similar to the tetanus receptor characterized in mammalian brain membranes (Lee et al., 1979; Rogers and Snyder, 1981). This cell line has also been useful in the study of the events that occur subsequent to initial binding. Using these cells, we have developed methods that permit distinction between surface binding and toxin uptake, and we report here the charactcristics of a receptor-mediated toxin internalization process. Preliminary reports of this work have been published (Rogers, 1983; Staub et al., 1984).

\section{Materials and Methods}

\section{Materials}

Mixed brain gangliosides, BSA (recrystallized), oligomycin, 2-deoxyglucose, phenylmethyl sulfonyl fluoride (PMSF), benzamidine, $\gamma$-aminocaproic acid, and pronase (Streptomyces griseus, Type XIV) were obtained from Sigma. Dulbecco's modified Eagle's medium (DMEM) and fetal calf serum were purchased from Hazlton Dutchland (Denver, PA). Tetanus toxin was the kind gift of Dr. R. O. Thomson, Wellcome Research Laboratories (Beckenham, England). Horse tetanus antitoxin was purchased from Sclavo Labs (Wayne, NJ). ${ }^{125}$ I-Bolton-Hunter reagent was purchased from Ncw England Nuclcar. All other chemicals 
were purchased as reagent gradc. The following tissue culture plasticware was used: $75 \mathrm{~cm}^{2}$ tissue culture flasks (Corning); $17 \mathrm{~mm}$ multiwell plates (Falcon); and $35 \mathrm{~mm}$ multiwell plates and $35 \mathrm{~mm}$ petri dishes (Nunc).

\section{Cell culture}

N18-RE-105 cells (mouse neuroblastoma clone N18TG-2-Fischer rat $18 \mathrm{~d}$ embryonic neural retina) were cultured as recently described (Malouf et al., 1984a, b). The day before experiments, cells were transferred to one of the following: 35 or $17 \mathrm{~mm}$ well multicluster dishes or $35 \mathrm{~mm}$ petri dishes. Cells were subcultured by removing the growth medium and replacing it with $10 \mathrm{ml}$ of $\mathrm{Ca}^{2+}, \mathrm{Mg}^{2+}$-free PBS: $137 \mathrm{~mm} \mathrm{NaCl}$, $5.22 \mathrm{mM} \mathrm{KCl}, 0.168 \mathrm{mM} \mathrm{Na}_{2} \mathrm{HPO}_{4}, 0.22 \mathrm{mM} \mathrm{KH} \mathrm{PO}_{4}, \mathrm{pH}$ 7.4. After $10 \mathrm{~min}$, the cells were removed from the flasks by agitation, collected by centrifugation at $250 \times g$ for $5 \mathrm{~min}$, and reseeded in growth medium at densities specified below for each experiment.

\section{Membrane preparation}

Membranes were prepared from N18-RE-105 cells in the following manner. Cells were removed from the culture flasks and collected as described above. The cells were resuspended in $0.25 \mathrm{M}$ sucrose, $20 \mathrm{~mm}$ Tris, $30 \mathrm{~mm} \mathrm{NaCl}, 1 \mathrm{~mm} \mathrm{CaCl}, 1 \mathrm{~mm} \mathrm{MgCl}, \mathrm{pH} 7.0$, and homogenized for $30 \mathrm{sec}$ with a Brinkman Polytron, setting 7 . This homogenate was centrifuged at $50,000 \times g$ for $10 \mathrm{~min}$ at $4^{\circ} \mathrm{C}$. The supernatant was removed by aspiration. The pellet was resuspended in fresh buffer by homogenization and centrifuged as above for $10 \mathrm{~min}$. The washed pellet was resuspended with a Teflon-glass homogenizer to an approximate final concentration of $2 \mathrm{mg}$ protein/ml. Aliquots were frozen on dry ice and stored at $-70^{\circ} \mathrm{C}$ until use. Rat (Sprague-Dawley) synaptic plasma membranes (SPM) were prepared by the method of Rogers and Snyder (1981).

\section{Ganglioside extraction and purification}

Gangliosides from N18-RE-105 cells ( 20 confluent $75 \mathrm{~cm}^{2}$ tissue culture flasks) were extracted and partially purified by solvent partitioning and dialysis as described previously (Dahms and Schnaar, 1983). Ganglioside analysis was performed by thin-layer chromatography (TLC) on silica gel-60 coated glass plates (E. Merck \#5763) using chloroform: methanol: $0.25 \%$ aqueous $\mathrm{KCl}(60: 35: 8)$ as solvent. Gangliosides were detected with an acid/resorcinol reagent specific for sialic acid and quantitated with a scanning densitometer as described previously (Dahms and Schnaar, 1983). Purified bovine brain ganglioside standards were prepared by the methods of Fredman (1980).

N18-RE-105 gangliosides were purified further by DEAE-Sepharose chromatography and Iatrobead (Iatron Chemical Co., Tokyo) silicic acid chromatography. Briefly, the gangliosides were evaporated to dryness, resuspended in $0.5 \mathrm{ml}$ of chloroform : methanol : water (120:60:9), and placed on a $1 \mathrm{ml}$ DEAE-Sepharose column pre-equilibrated with the same solvent. The column was washed first with $5 \mathrm{ml}$ of the same solvent, then $5 \mathrm{ml}$ of methanol, and gangliosides were eluted with a step-gradient consisting of 10,20 , and then $30 \mathrm{~mm}$ potassium acetate in methanol $(10 \mathrm{ml} / \mathrm{step})$. Each fraction was evaporated, resuspended in a small volume of water, and dialyzed overnight at $4^{\circ} \mathrm{C}$ to remove the salt.

The N18-RE-105 gangliosides cochromatographing with the bovine brain standard $\mathrm{GD}_{\mathrm{la}}$ and $\mathrm{GT}_{\mathrm{lb}}$ were purified further using Iatrobead silicic acid chromatography. The DEAE-Sepharose fractions containing $\mathrm{GD}_{1 \mathrm{a}}$ or $\mathrm{GT}_{\mathrm{lb}}$ were dissolved in $10 \mu \mathrm{l}$ of chloroform : methanol : water (65:25:4) and chloroform : methanol : $2.5 \mathrm{M} \mathrm{NH}_{4} \mathrm{OH}(60: 32: 7)$, respectively, applied to a $2 \times 75 \mathrm{~mm}$ Iatrobead column, and eluted in 30 drop fractions of the same solvent. The eluant was examined by TLC and appropriate fractions pooled.

\section{Partial acid hydrolysis of gangliosides}

N18-RE-105 GD and $\mathrm{GT}_{1 \mathrm{~b}}$ were evaporated in $12 \times 75 \mathrm{~mm}$ glass tubes, resuspended in $0.2 \mathrm{ml}$ of $0.1 \mathrm{~N}$ aqueous formic acid, and heated at $100^{\circ} \mathrm{C}$ for $20 \mathrm{~min}$. The acid was neutralized by addition of $20 \mu \mathrm{l}$ of $1.0 \mathrm{~N} \mathrm{NaOH}$; then methanol $(1.47 \mathrm{ml})$ and chloroform $(2.93 \mathrm{ml})$ were added. The solution was desalted on a $0.5 \mathrm{ml}$ column of Sephadex G25 pre-equilibrated with chloroform : methanol : water $(120: 60: 9)$ as described previously (Dahms and Schnaar, 1983). The effluent was evaporated, resuspended in a small volume of chloroform : methanol : water (4:8:3) and examined by TLC.

\section{Gel electrophoresis}

SDS gel electrophoresis was performed using the method of Laemmli (1970). All samples were incubated in a denaturation buffer of $50 \mathrm{~mm}$ Tris, $0.3 \mathrm{~mm} \beta$-mercaptoethanol, $4 \%$ SDS, $\mathrm{pH} 6.8$, for $10 \mathrm{~min}$ at $100^{\circ} \mathrm{C}$. Generally, $10,000 \mathrm{cpm}$ of ${ }^{125}$ I-tetanus toxin were layered onto the tracks of the SDS slab gel, which was prepared with a $7-15 \%$ linear gradient of acrylamide. Gels were dried and autoradiograms prepared by incubating the dried gel with unexposed X-ray film at $-70^{\circ} \mathrm{C}$ for $4 \mathrm{hr}$ in cassettes cquipped with intensifying screens (Quanta 3, Dupont, Wilmington, DE).

\section{Biouctivity of toxin}

Bioassays of ${ }^{125}$ I-tetanus toxin were performed as previously described (Rogers and Snyder, 1981). Groups of mice were injected with serial dilutions of ${ }^{125}$ I-tetanus toxin stock solutions or radiolabeled toxin that was dissociated from N18-RE-105 cells after binding at $0^{\circ} \mathrm{C}$. A minimal lethal dose was defined as the highest dilution of ${ }^{125}$ I-toxin that caused death in all three mice after $96 \mathrm{hr}$.

\section{Binding experiments}

Radiolabeled tetanus toxin was prepared to a specific radioactivity of $400-600 \mathrm{Ci} / \mathrm{mmol}$ by incubating $100 \mu \mathrm{g}$ of toxin with $1 \mathrm{mCi}$ of ${ }^{125} \mathrm{I}-p-$ hydroxyphenylpropionic $N$-succinimidyl-ester (Bolton-Hunter reagent) by methods adapted from Bolton and Hunter (1973) as previously described (Rogers and Snyder, 1981). Binding studies with N18-RE-105 membranes and rat SPM preparations were performed using a microcentrifugation assay as previously described (Rogers and Snyder, 1981). The binding buffer, unless otherwise indicated, consisted of $0.25 \mathrm{M}$ sucrose, $20 \mathrm{~mm}$ Tris, $30 \mathrm{~mm} \mathrm{NaCl}, 1 \mathrm{~mm} \mathrm{CaCl}, 1 \mathrm{~mm} \mathrm{MgCl}, 0.25 \%$ BSA, pH 7.0. The rinse buffer was the binding buffer without BSA. The binding of ${ }^{125}$ I-tetanus toxin was linear up to $20 \mathrm{ng}$ of protein for rat SPM and up to $500 \mathrm{ng}$ of protein for the N18-RE-105 membranes. The specific binding was determined as the difference between the total binding and the nonspecific binding. The latter was estimated by incubating membranes in an identical manner except that $50 \mathrm{~nm}$ unlabeled toxin was added. Using these incubation conditions, at least $90 \%$ of the nonspecific binding was due to ligand binding to the tubes alone, as determined in control experiments. Incubations in which three units of antitoxin were added gave identical values to those obtained in the presence of excess cold toxin. Therefore, antitoxin was used in most experiments as a measure of nonspecific binding. This method has been used previously to detcrmine "'I-toxin nonspecific binding (Lee et al., 1979; Yavin et al., 1981). Typically, when $20 \mathrm{ng}$ of rat SPM protein or $200 \mathrm{ng}$ of N18-RE-105 membrane protein was included in the incubation with $0.2 \mathrm{nM}{ }^{125}$ I-tetanus toxin $(50,000 \mathrm{cpm})$ at $0^{\circ} \mathrm{C}$, the total binding reached a plateau after $2 \mathrm{hr}$ and was about $2500 \mathrm{cpm}$; the nonspecific binding was about $500 \mathrm{cpm}$. Scatchard plots were performed by incubating fixed concentrations of ${ }^{125}$ I-tetanus toxin with increasing concentrations of cold toxin and analyzing the data as previously reported (Rogers and Snyder, 1981). Protein was determined by the method of Bradford (1976) using BSA as a standard.

In binding experiments with cells attached to culture dishes, growth medium was removed and replaced with binding buffer (described above) containing ${ }^{125}$ I-tetanus toxin in a concentration range of $0.1-0.4 \mathrm{~nm}$. Incubations were terminated by removing the incubation medium and replacing it with $1-2 \mathrm{ml}$ of a rinse buffer (binding buffer without BSA). After $5 \mathrm{~min}$, the rinse buffer was gently aspirated and the cells were solubilized in $1 \% \mathrm{SDS}, 0.5 \mathrm{~N} \mathrm{NaOH}$. The solutions were then transferred to test tubes and counted in a gamma radiation coun ter at $59 \%$ efficiency. Protein was determined in an aliquot of a $0.005 \%$ SDS extract from individual wells using the Coomassie Blue assay according to Bradford (1976). The protocols were designed so that greater than $90 \%$ of cell protein remained bound to the dishes during the various incubations and rinses required. Specific binding was determined as described above. All data points were performed in duplicate or triplicate, with a variation of $10 \%$ or less, and each experiment was repeated three times. In a typical experiment, when $0.2 \mathrm{nM}{ }^{125}$ I-tetanus toxin $(50,000 \mathrm{cpm})$ was incubated with N18-RE-105 cells $(30,000$ cells $/ 1.7 \mathrm{~cm}$ well, $20 \mu \mathrm{g}$ of cell protein) in $1 \mathrm{ml}$ of binding buffer, total binding was approximately $2000 \mathrm{cpm}$ and nonspecific binding was about $500 \mathrm{cpm}$.

\section{Cell viability}

Changes in cell viability were assessed by two independent methods. In the first procedure, the ability of cells to exclude $0.04 \%$ Trypan Blue 
was used as a measure of viability. A more quantitative method was also employed, which used the amount of lactate dehydrogenase released into the medium as a measure of nonviable cells (Schnaar and Schaffner, 1981).

\section{ATP assay}

ATP content of intact N18-RE-105 cells attached to culture dishes was determined by first extracting ATP from the cells and then quantitating the ATP content of the extract using a luciferin-luciferase fluorimetric assay according to Stanley and Williams (1969). To quantitate ATP in cells attached to culture dishes, the cells (generally $30,000 / 1.7 \mathrm{~cm}$ well) were fast-frozen in a dry ice-alcohol bath and then placed on ice. An extraction solution (6\% perchloric acid, $2.5 \mathrm{~mm}$ EDTA) was added, and the resulting slurry scraped from the plate with a rubber policeman. The suspension was transferred to a $1.5 \mathrm{ml}$ microfuge tube, and the samples were centrifuged for $2 \mathrm{~min}$ at $12,000 \times \mathrm{g}$. The supernatant was then neutralized with $5 \mathrm{M} \mathrm{K}_{2} \mathrm{CO}_{3}$. The entire sample was recentrifuged at $12,000 \times g$ for $2 \mathrm{~min}$, and the supernatant cell extract was removed and frozen on dry ice. Extracts were stored at $-70^{\circ} \mathrm{C}$ and used within $48 \mathrm{hr}$. Control experiments indicated that no ATP was lost during this storage procedure. Bioluminescence measurements were made on a model A3330 Packard Tricard liquid-scintillation spectrophotometer. ATP levels were found to be 10-11 nmol ATP/mg of cell protein for cells attached to culture dishes.

\section{Protease digestion of ${ }^{125}$ I-tetanus toxin}

In preliminary experiments, optimal conditions for the degradation of unbound ${ }^{125}$ I-tetanus toxin were determined by assessing toxin degradation on SDS slab gels after the ligand had been exposed to a variety of enzymes as described below. The conditions that produced complete degradation of free ${ }^{125} \mathrm{I}$-labeled toxin were $5.0 \mu \mathrm{g} / \mathrm{ml}$ pronase incubated for $10 \mathrm{~min}$ at $37^{\circ} \mathrm{C}$ in sucrose binding buffer without BSA. Control experiments showed that the proteolytic activity of this protease preparation could be completely stopped by adding an inhibitor cocktail that contained $1 \mathrm{~mm}$ PMSF, $1 \mathrm{~mm}$ benzamidine, and $5 \mathrm{~mm} \gamma$-aminocaproic acid.

The experiments with membranes were done in a similar manner. N18-RE-105 membranes were incubated with ${ }^{125}$ I-labeled toxin as described above. The binding reactions were terminated by centrifugation at $12,000 \times g$ for 2 min (Beckman Microfuge No. 12). The incubation medium was removed by aspiration, and the pellet was resuspended in rinse buffer containing $20 \mu \mathrm{g} / \mathrm{ml}$ pronase. The suspension was incubated for $10 \mathrm{~min}$ at $37^{\circ} \mathrm{C}$. After the inhibitor cocktail was added to terminate the reaction, the membranes were collected by centrifugation. The pellets were rinsed with $1 \mathrm{ml}$ of rinse buffer and then recentrifuged. The amount of radioactivity still bound to the membranes was determined by counting the pellets in a gamma counter.

For degradation of ${ }^{125}$ I-tetanus toxin bound to N 18 -RE- 105 cells, cells attached to $35 \mathrm{~mm}$ multiwell dishes were incubated with ${ }^{125}$ I-tetanus toxin in $2 \mathrm{ml}$ of incubation buffer for various time periods. The incubation medium was removed by aspiration, and the cells were rinsed with $2 \mathrm{ml}$ of rinse buffer. The cells were incubated at $37^{\circ} \mathrm{C}$ in $2 \mathrm{ml}$ of rinse buffer containing either 20 or $40 \mu \mathrm{g} / \mathrm{ml}$ of pronase for 10 or $5 \mathrm{~min}$, respectively. The inhibitor cocktail was added to terminate the reaction, and the cells, $90 \%$ of which remained attached (measured as cell protein), were gently rinsed with $2 \mathrm{ml}$ of rinse buffer at $37^{\circ} \mathrm{C}$. The cells were then removed from the dishes and counted in a gamma counter, as described above. All of the data were corrected for the small losses in protein (less than $15 \%$ ) that were observed.

\section{Results}

Preliminary studies indicated that N18-RE-105 cells incubated with $0.1 \mathrm{~nm}{ }^{125}$ I-tetanus toxin display a high capacity for ${ }^{125} \mathrm{I}$ toxin binding (Staub et al., 1984). In fact, these cells have a much higher capacity for tetanus toxin binding compared to the NCB-20 cell line, which has been cited to contain the highest levels of toxin receptor of any reported cell line (Yavin and Habig, 1984). When both cell lines were incubated with ${ }^{125} \mathrm{I}$ tetanus toxin under identical conditions $\left(0.1 \mathrm{nM}^{125} \mathrm{I}\right.$-toxin, $37^{\circ} \mathrm{C}$, $2 \mathrm{hr})$, the N18-RE-105 cells bound sixfold more toxin $(3.2 \pm$ $0.1 \mathrm{pmol} / \mathrm{mg}$ protein) than the NCB-20 cells $(0.52 \pm 0.02 \mathrm{pmol} /$ mg protein).
Table 1. Specificity of ${ }^{125}$ I-tetanus toxin binding to N18-RE-105 cells

Total ${ }^{125}$ I-tetanus toxin bound

Compound added $\left(B / B_{0}\right)(\%)$

\section{Control}

100

Unlabeled tetanus toxin $(10 \mu \mathrm{M})$

Unlabeled tetanus toxin (10 $\mathrm{nm})$

Tetanus toxoid $(10 \mu \mathrm{M})$

Tetanus antitoxin ( 2 units)

Mixed gangliosides $(20 \mu \mathrm{M})$

N18-RE- 105 cells $\left(20,000\right.$ cells/tube) were incubated with $0.2 \mathrm{~nm}{ }^{125}$ [-tetanus toxin in $1.0 \mathrm{ml}$ binding buffer for $2 \mathrm{hr}$ at $0^{\circ} \mathrm{C}$ in the presence of the compounds as indicated. The specific binding was quantitated as described under Materials and Methods. ${ }^{2}$ I-tetanus toxin binding is expressed as the percentage bound relative to control values $\left(0.52 \pm 0.05 \mathrm{pmol} / \mathrm{mg}\right.$ protein). These ${ }^{125} \mathrm{I}$-toxin experiments were repeated three times with a variation of $10 \%$.

A number of studies were performed to determine if the tetanus receptor on the $\mathrm{N} 18$-RE- 105 cells is similar to the receptor previously characterized on mammalian brain membranes (Lee et al., 1979; Rogers and Snyder, 1981). First, the binding properties of the tetanus toxin receptor on microsomal preparations from N 18-RE-105 cells were examined. The binding of ${ }^{125}$ Itetanus toxin to either N18-RE-105 membranes or rat SPM was stimulated threefold when the $\mathrm{pH}$ was decreased from $\mathrm{pH} 8$ to 5.5. The binding of ${ }^{125}$ I-toxin to either membrane preparation was decreased by increasing ionic strength. For example, relative to salt-free controls, the binding of $0.1 \mathrm{nM}^{125} \mathrm{I}$-tetanus toxin to both membranes was decreased 10 -fold when $125 \mathrm{~mm} \mathrm{NaCl}$ was added to the incubation buffer. The regulation of ${ }^{125}$ I-tetanus toxin binding by $\mathrm{NaCl}$ appears to be an ionic strength effect since similar results were obtained with $\mathrm{KCl}$, choline chloride, and $\mathrm{CaCl}_{2}$ (data not shown). As a further comparison, the effect of incubation temperature on ${ }^{125}$ I-tetanus toxin binding to membranes was also determined. The binding of ${ }^{125}$ I-toxin to both membrane systems was decreased by $60 \%$ when the incubation temperature was increased from $4^{\circ} \mathrm{C}$ to $37^{\circ} \mathrm{C}$. These results demonstrate that the tetanus receptor on the N18-RE-105 cells is similar to the receptor characterized on mammalian brain membranes.

It was clear from these studies that the "optimum" binding conditions of low $\mathrm{pH}$ and ionic strength were not physiological and thus hazardous to cell viability. Therefore, the incubation buffer (see Materials and Methods) used in most of the experiments is a compromise between conditions that "optimize" toxin-cell interactions and conditions that maintain viable cells for a reasonable period of time.

Several experiments were performed to verify that the N18RE-105 cells and microsomal preparations were binding authentic ${ }^{125}$ I-tetanus toxin. The bound ligand was separated from the free ligand and analyzed by SDS gel electrophoresis autoradiograms. The radioactivity bound to intact cells or broken cell membrane preparations migrated identically with ${ }^{125} \mathrm{I}$-tetanus toxin. The unbound radioactivity remaining in the supernatant was analyzed in the same manner. Autoradiograms of SDS gels showed that this unbound radioactive material migrated as intact ${ }^{125}$ I-labeled toxin (data not shown). This indicates that no significant proteolysis of the ligand occurred during the course of normal incubations.

To further analyze the biological relevance of the toxin-cell interactions, the biological activity of the bound radioactivity was determined. This is an important control since it is well known that preparations of ${ }^{125}$ I-labeled tetanus toxin also contain radiolabeled biologically inactive toxoid (Lee et al., 1979; Rogers and Snyder, 1981). ${ }^{125}$ I-tetanus toxin that was bound to 


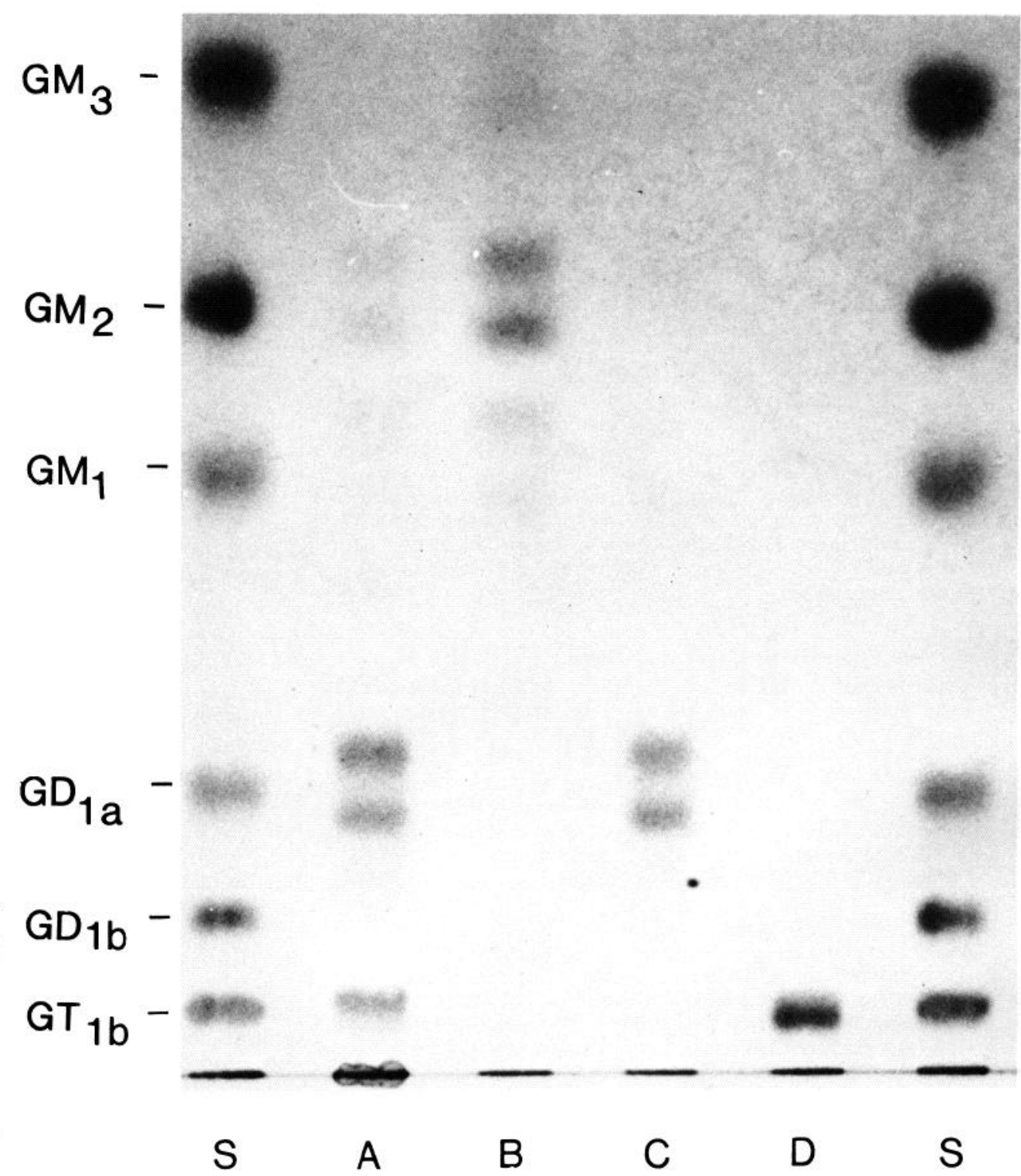

Figure 1. Purification and separation of N18-RE-105 gangliosides. Gangliosides from N18-RE-105 cells were extracted and purified by DEAE-Sepharose and Iatrobead silicic acid chromatography as described in the text. The gangliosides were subjected to TLC in chloroform : methanol: $0.25 \%$ (wt/ vol) potassium chloride in water $(60$ : $35: 8)$ and visualized with a resorcinol spray reagent: $S$, bovine brain standards as indicated at left; $A$, total N18RE-105 gangliosides $(0.7 \mathrm{nmol}) ; B, C$, and $D$, purified mono-, di-, and trisialoganglioside fractions, respectively ( $0.3 \mathrm{nmol} /$ lane) .

intact cells at $0^{\circ} \mathrm{C}$ was recovered, and the biological potency was determined as described under Materials and Methods. The bound toxin had a potency of $590 \mathrm{cpm} / \mathrm{lethal}$ dose. The native ${ }^{125}$ I-labeled toxin stock solution had a potency of $650 \mathrm{cpm} / \mathrm{lethal}$ dose. Therefore, the N18-RE-105 cells bind biologically active toxin under the incubation conditions used in these experiments.

The specificity of the N18-RE-105 tetanus toxin receptor was determined in incubations using intact cells. As shown in Table 1 , unlabeled toxin and tetanus antitoxin inhibited binding, whereas biologically inactive tetanus toxoid did not compete for the receptor. Further, mixed brain gangliosides were very effective at inhibiting binding to N18-RE-105 cells. These results are consistent with previous studies on ${ }^{125} \mathrm{I}$-toxin interactions with rat brain membranes and primary cultured neurons (Rogers and Snyder, 1981; Yavin et al., 1981).

Since complex gangliosides have been implicated as receptors for tetanus toxin (Holmgren et al., 1980; Rogers and Snyder, 1981), we extracted the gangliosides from N18-RE-105 cells and examined them by TLC (Fig. 1). In contrast to previously characterized cell lines, which contain principally simple mono- and disialogangliosides, N18-RE-105 cells contain material that cochromatographs with standard $\mathrm{GT}_{1 \mathrm{~b}}, \mathrm{GD}_{\mathrm{la}}$, and $\mathrm{GD}_{\mathrm{lb}}$ (slight), as well as $\mathrm{GM}_{1}$ and $\mathrm{GM}_{2}$. The gangliosides from N18-RE-105 cells were further characterized by separation into three pools (tentatively called mono-, di-, and trisialogangliosides) via DEAE-Sepharose and Iatrobead silicic acid chromatography (Fig. 1). The species that cochromatographed with bovine brain standards $G_{1 \mathrm{a}}$ and $\mathrm{GT}_{1 \mathrm{~b}}$ were subjected to TLC analysis after partial formic acid hydrolysis under conditions that remove a portion of the sialic acid residues (Fig. 2). It should be noted that the appearance of "doublet" ganglioside species is common with cultured cells and has previously been shown to reflect variation in the ceramide portion of gangliosides having identical carbohydrate chains (Dahms and Schnaar, 1983). The ganglioside doublet that cochromatographed with bovine brain $\mathrm{GD}_{\text {la }}$ produced one new resorcinol-positive hydrolysis product (doublet) with a mobility similar to that of bovine brain $\mathrm{GM}_{1}$ (panel A). In contrast, the ganglioside doublet which cochromatographed with bovine brain $\mathrm{GT}_{1 \mathrm{~b}}$ produced three doublet products with mobilities similar to $\mathrm{GD}_{1 \mathrm{~b}}, \mathrm{GD}_{1 \mathrm{a}}$, and $\mathrm{GM}_{1}$ standards (panel B). These hydrolysis patterns are consistent with the designation of the two purified N18-RE-105 gangliosides as $\mathrm{GD}_{\mathrm{la}}$ and $\mathrm{GT}_{1 \mathrm{~b}}$.

In order to quantitate the binding interactions of ${ }^{125} \mathrm{I}$-tetanus toxin with N18-RE-105 membranes, competition binding stud- 


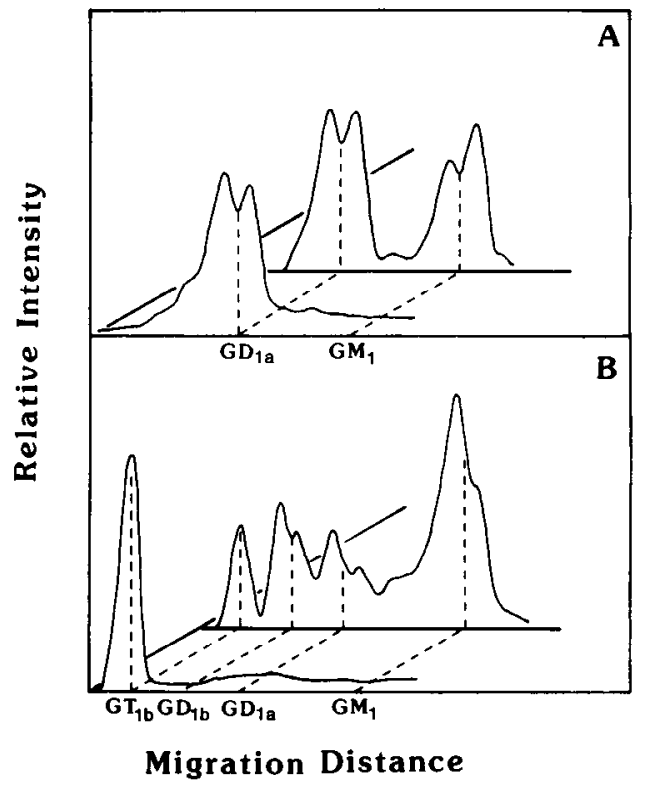

Figure 2. Partial acid hydrolysis of purified N18-RE-105 gangliosides. Purified disialogangliosides $(A)$ and trisialogangliosides $(B)$ were partially hydrolyzed with formic acid, neutralized, desalted, and subjected to TLC [in chloroform : methanol: $0.25 \%(\mathrm{wt} / \mathrm{vol})$ potassium chluride in water $(60: 35: 8)]$ as described in the text. Unhydrolyzed ganglioside fractions (foreground traces) and matched partial hydrolysates (background traces) were visualized using a resorcinol spray reagent and quantitated using a Kontes Fiber Optic Scanner. Mobilities of bovine brain ganglioside standards chromatographed on the same plate are indicated at the bottom of the figure.

ies were performed. As shown in Figure 3, unlabeled tetanus toxin was a potent inhibitor of ${ }^{125}$ I-toxin binding to N18-RE105 membranes and to rat SPM with $K_{\mathrm{I}}$ 's in the subnanomolar range. Analogous to the results with rat SPM, the dose-inhibition curves for N18-RE-105 membranes were monophasic and were analyzed as a single class of high-affinity binding sites by the use of Scatchard plots (Fig. 3, inset). The high-affinity binding parameters from three separate experiments for N18-RE105 membranes and rat SPM were $K_{\mathrm{D}}=0.62 \pm 0.05 \mathrm{nM}, B_{\max }=$ $196 \pm 45 \mathrm{pmol} / \mathrm{mg}$ protein and $K_{\mathrm{D}}=0.39 \pm 0.05 \mathrm{nM}, B_{\max }=$ $520 \pm 61 \mathrm{pmol} / \mathrm{mg}$ of protein, respectively.

Competition binding curves with intact N18-RE-105 cells were markedly different from the results with broken cell membranes. As shown in Figure 3, the dose-inhibition curves for the intact cells at $0^{\circ} \mathrm{C}$ were broader than those generated using membranes. Scatchard plots of these binding results were not monophasic and were difficult to interpret. Furthermore, at $37^{\circ} \mathrm{C}$, virtually none of the ${ }^{125}$ I-toxin was displaced by unlabeled toxin even when $500 \mathrm{~nm}$ tetanus toxin (a 2000-fold excess) was added (data not shown). The lack of binding inhibition at $37^{\circ} \mathrm{C}$ was not the result of increased ${ }^{125}$ I-toxin metabolism, as revealed by two experiments: (1) supernatant radioactivity comigrated with authentic ${ }^{125}$ I-toxin on SDS gels; (2) supernatant ${ }^{125}$ I-toxin could still bind when exposed to fresh cells at $0^{\circ} \mathrm{C}$. Antitoxin was effective in preventing binding of ${ }^{125}$ I-toxin to intact cells at 0 and $37^{\circ} \mathrm{C}$.

The lack of saturability of ${ }^{125} \mathrm{I}$-tetanus toxin binding at $37^{\circ} \mathrm{C}$ suggested that tetanus toxin was being internalized in these intact cells. We reasoned that if ${ }^{125}$ I-tetanus toxin was being transferred from the surface of the cell, then it should become resistant to proteolytic digestion. In the next series of experiments, we optimized conditions that would degrade ${ }^{125} \mathrm{I}$-tetanus toxin bound to membranes. Pronase at $5 \mu \mathrm{g} / \mathrm{ml}$ could completely degrade free ${ }^{125} \mathrm{I}$-toxin in $5 \mathrm{~min}$ at $37^{\circ} \mathrm{C}$. Fourfold higher concentrations of pronase $(20 \mu \mathrm{g} / \mathrm{ml})$ were required to completely degrade toxin that had been bound to N18-RE-105 microsomes at 37 or $0^{\circ} \mathrm{C}$ (Table 2). To test for toxin internalization, ${ }^{125} \mathrm{I}$ tetanus toxin was incubated at either 0 or $37^{\circ} \mathrm{C}$ for $2 \mathrm{hr}$ with cells attached to culture dishes. After removal of unbound ligand, the cells were treated with pronase and the amount of ${ }^{125} \mathrm{I}$ toxin remaining with the cells was determined. As shown in Table 2, when the incubations are done at $0^{\circ} \mathrm{C}$ with $20 \mu \mathrm{g} / \mathrm{ml}$ pronase, nearly all of the ${ }^{125} \mathrm{I}$-toxin was degraded. These data

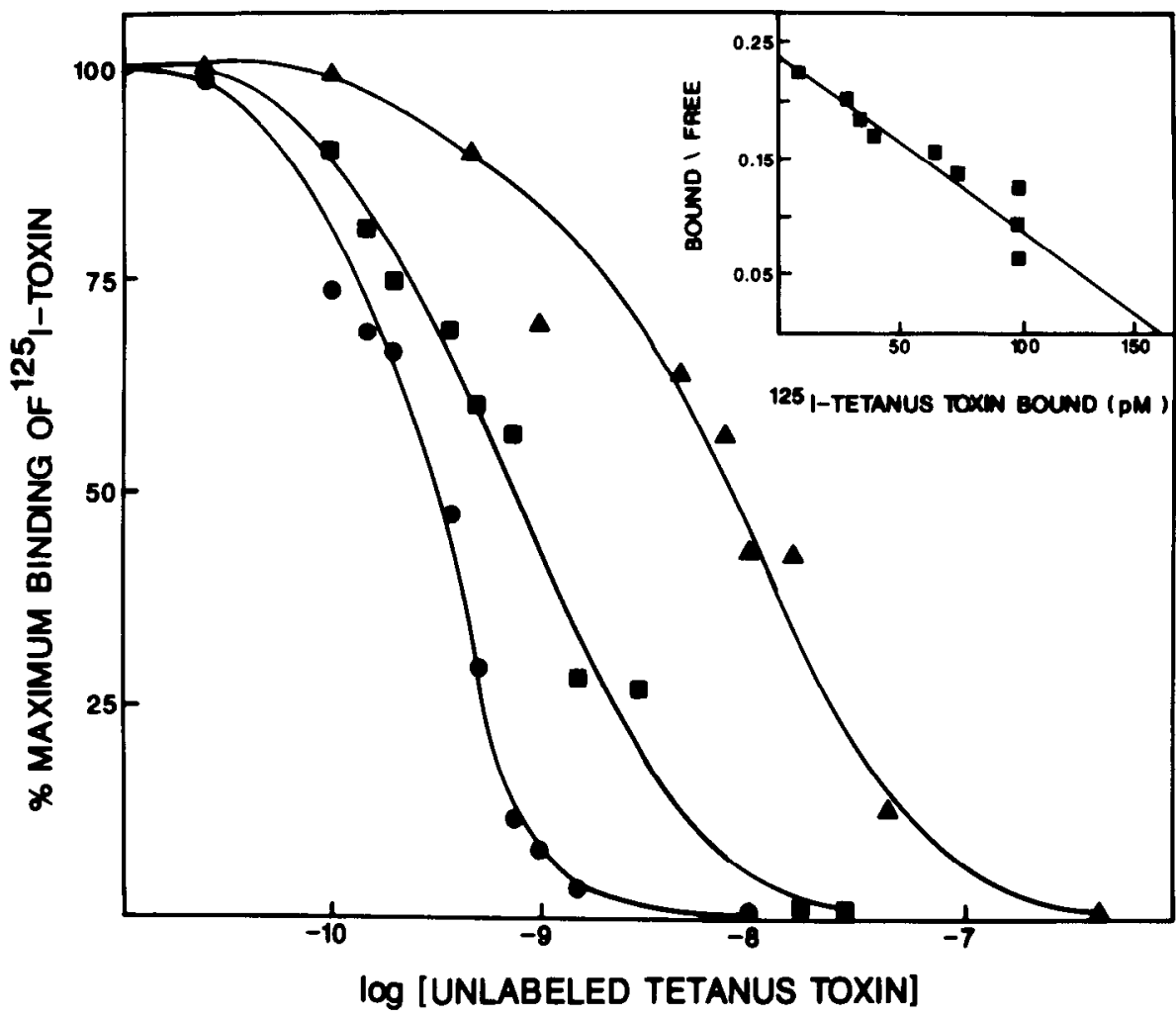

Figure 3. Competition of ${ }^{125}$ I-tetanus toxin binding with unlabeled toxin to rat SPM, N18-RE-105 membranes, and intact N18-RE- 105 cells at $0^{\circ} \mathrm{C}$. Binding conditions are described under Materials and Methods. ${ }^{25}$ I-tetanus toxin concentration was $0.2 \mathrm{nM}$. Protein concentrations were $20 \mathrm{ng} / 0.2 \mathrm{ml}, 500 \mathrm{ng} /$ $0.2 \mathrm{ml}$, and $20 \mu \mathrm{g} / 1.7 \mathrm{~cm}$ well for rat SPM(O), N18-RE-105 membranes ( $\square$ ), and intact N18-RE-105 cells (A), respectively. Inset, N18-RE-105 membrane data recalculated to fit a Scatchard plot. The experiments were repeated three times. 


\begin{tabular}{|c|c|c|c|}
\hline Preparation & $\begin{array}{l}\text { Concentration } \\
\text { of pronase } \\
(\mu \mathrm{g} / \mathrm{ml})\end{array}$ & $\begin{array}{l}\text { Incubation } \\
\text { temperature } \\
\left({ }^{\circ} \mathrm{C}\right)\end{array}$ & $\begin{array}{l}{ }^{125} I-t e t a n u s \\
\text { toxin re- } \\
\text { leased }(\%)\end{array}$ \\
\hline \multirow[t]{2}{*}{ Microsomes } & 5 & 0 & 65 \\
\hline & & 37 & 73 \\
\hline \multirow[t]{2}{*}{ Microsomes } & 20 & 0 & 98 \\
\hline & & 37 & 98 \\
\hline \multirow[t]{2}{*}{ N18-RE-105 cells } & 5 & 0 & 49 \\
\hline & & 37 & 34 \\
\hline \multirow[t]{2}{*}{ N18-RE-105 cells } & 20 & 0 & 94 \\
\hline & & 37 & 55 \\
\hline
\end{tabular}

N18-RE-105 cells, plated to a density of $10^{6}$ cells $/ 35 \mathrm{~mm}$ dish, or N18-RE-105 membranes $(200 \mu \mathrm{g})$ were incubated with $0.1 \mathrm{nM}{ }^{125}$-tetanus toxin for $2 \mathrm{hr}$ at 0 or $37^{\circ} \mathrm{C}$ as described under Materials and Methods. At the end of the incubations, the bound ligand was exposed to pronase, at the concentrations indicated, for 10 min at $37^{\circ} \mathrm{C}$ as described in detail under Materials and Methods. The percentage of released ${ }^{25}$ I-toxin was determined relative to controls in which the tissue was not exposed to pronase. Control levels of tetanus toxin binding in these experiments were $0.095 \mathrm{pmol} / \mathrm{mg}$ protein and $0.034 \mathrm{pmol} / \mathrm{mg}$ protein for microsomes and intact cells, respectively. The results are the means of three experiments with a variation of $10 \%$.

are in agreement with the broken cell membrane experiments. In contrast, when ${ }^{125} \mathrm{I}$-tetanus toxin was bound to cells at $37^{\circ} \mathrm{C}$, only $55 \%$ of the bound ${ }^{125}$ I-toxin was accessible to pronase; while under identical conditions, all of the membrane bound ${ }^{125} \mathrm{I}$ tetanus toxin was pronase-accessible.

The appearance rate of the protease-resistant toxin was characterized by incubating the cells with ${ }^{125}$ I-tetanus toxin for various times and then exposing the labeled cells to pronase. Within 5 min, a significant fraction of nonreleasable ${ }^{125}$ I-tetanus toxin appeared in cells incubated at $37^{\circ} \mathrm{C}$ compared to controls incubated at $0^{\circ} \mathrm{C}$. After $15 \mathrm{~min}$, the fraction of toxin that was pronase-resistant reached a maximum of about $45 \%$. However, the total cell-associated toxin levels continued to increase (Fig. 4 , inset), so that uptake and binding of toxin were still occurring. By the end of the experiment, approximately 11,000 molecules of ${ }^{125}$ I-tetanus toxin per cell had been transferred to a compartment inaccessible to pronase. It is interesting that the total amount of cell-associated ${ }^{125}$ I-toxin at $0^{\circ} \mathrm{C}$, at which little internalization occurred, was identical to the amount bound at $37^{\circ} \mathrm{C}$, at which considerable internalization was measured (Fig. 4 , inset). These data indicate that a rate-limiting binding step is followed by a more rapid uptake of toxin.These data suggest that receptor recycling did not occur during the course of the experiments. Further studies are needed to confirm this possibility.

Temperature-pulse experiments were performed so that the internalization of surface bound ${ }^{125}$ I-toxin could be studied separately from the initial receptor binding process. In these experiments, N18-RE-105 cells were incubated for $10 \mathrm{~min}$ at $0^{\circ} \mathrm{C}$ with ${ }^{125} I$-tetanus toxin. The unbound ${ }^{125} \mathrm{I}$-toxin was removed by washing, and the labeled cells were either warmed to $37^{\circ} \mathrm{C}$ or maintained at $0^{\circ} \mathrm{C}$. The amount of releasable ${ }^{125} \mathrm{I}$-label was quantitated over time. The results are shown in Figure 5. As expected, when the cells were maintained at $0^{\circ} \mathrm{C}$, about $90 \%$ of the radiolabel remaining on the cell was releasable by pronase treatment. In contrast, at $37^{\circ} \mathrm{C},{ }^{125} \mathrm{I}$-toxin rapidly disappeared from the surface, and within $10 \mathrm{~min}$, approximately $70 \%$ of the total cell-associated ${ }^{125} \mathrm{I}$-toxin was pronase-resistant. These results reveal that the uptake of ${ }^{125} \mathrm{I}$-toxin, once it is bound to the cell surface, is rapid at $37^{\circ} \mathrm{C}$.

To further characterize the apparent internalization, the effect of metabolic inhibitors on the uptake of ${ }^{125}$ I-tetanus toxin

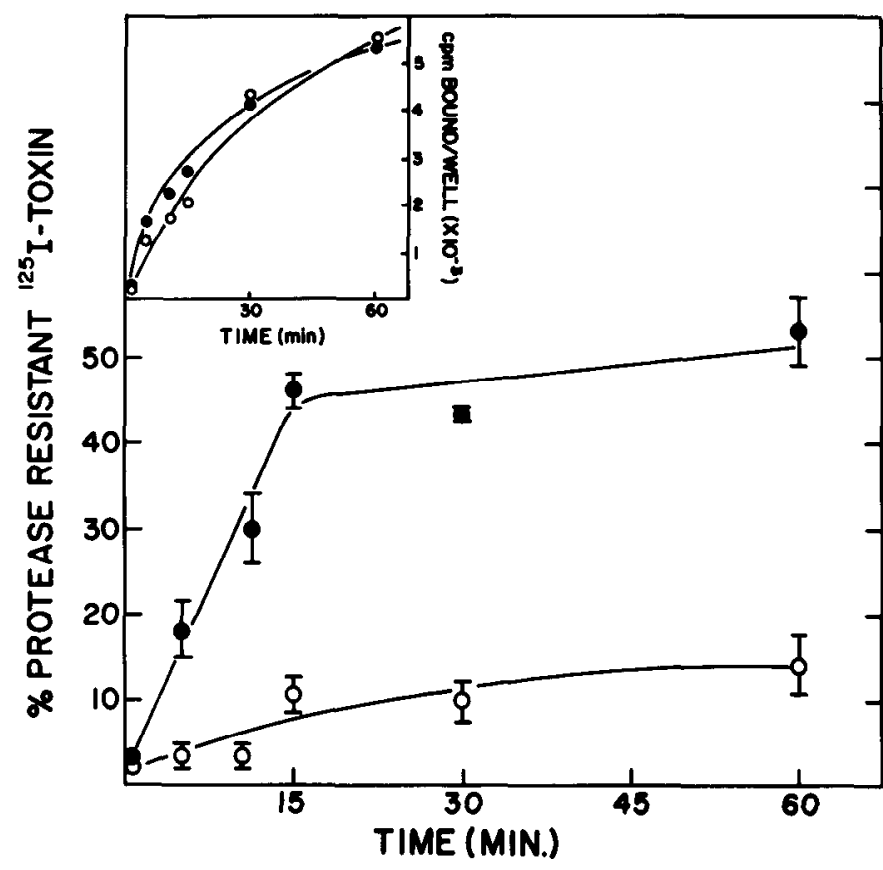

Figure 4. Characterization of ${ }^{125}$ I-tetanus toxin internalization. N18RE- 105 cells $\left(5 \times 10^{5}\right.$ cells plated onto $35 \mathrm{~mm}$ dishes, $500 \mu \mathrm{g}$ cell protein) were incubated with $0.4 \mathrm{nM}^{125}$ I-tetanus toxin in $2 \mathrm{ml}$ of incubation buffer at either $0^{\circ} \mathrm{C}(\mathrm{O})$ or $37^{\circ} \mathrm{C}(\bullet)$. At the indicated times, the cells were rinsed and incubated with pronase as described in detail in Materials and Methods. Each point is expressed as a percentage of control values, which represent the specific binding of ${ }^{125}$ I-toxin bound to cells not treated with pronase. The data points are the means of three experiments $( \pm \mathrm{SE})$, each performed in duplicate. Inset, Specific binding of ${ }^{125}$ I-tetanus toxin to untreated cells at $0^{\circ} \mathrm{C}(\mathrm{O})$ or $37^{\circ} \mathrm{C}(\mathbf{O})$. Nonspecific binding, which was identical at either temperature, was based on inhibition by antitoxin and has been subtracted from the total binding values.

by intact cells was examined. In these experiments, cells were pretreated with oligomycin-rotenone under conditions that consistently reduced ATP levels by $95 \%$ in control experiments. The cells were then incubated with ${ }^{125}$ I-toxin, and the amount of pronase-resistant label was quantitated. As shown in Figure 6 , treatment of the cells with metabolic inhibitors resulted in an inhibition of ${ }^{125} \mathrm{I}$-toxin internalization. After $30 \mathrm{~min}$ at $37^{\circ} \mathrm{C}$, the amount of toxin internalized was identical to that observed in control experiments with untreated cells at $0^{\circ} \mathrm{C}$. No difference was detected in the total amount of cell-associated ${ }^{125}$ I-toxin between cells treated with oligomycin-rotenone and untreated controls. Binding studies on N18-RE-105 membranes clearly demonstrated that oligomycin-rotenone had no effect on ${ }^{125} \mathrm{I}-$ toxin binding at either $0^{\circ} \mathrm{C}$ (control, $2.50 \mathrm{pmol}$ toxin bound $/ \mathrm{mg}$ protein; oligomycin-rotenone, $2.40 \mathrm{pmol} / \mathrm{mg}$ protein) or $37^{\circ} \mathrm{C}$ (control, $2.75 \mathrm{pmol}$ toxin/mg protein; oligomycin-rotenone, 2.35 $\mathrm{pmol} / \mathrm{mg}$ protein). Taken together, these data demonstrate that the metabolic inhibitors alter a process that occurs after initial binding interactions.

\section{Discussion}

The major goal of this study was to characterize events in the tetanus toxin intoxication process that occur after initial receptor binding. We have identified a neuronal cell line that has high-affinity tetanus toxin receptors analogous to those identified in brain tissue. This cell line has been exploited to provide insights into the binding-internalization process. The major result is that a process has been identified in a homogeneous population of cells that involves a relatively slow binding of tetanus toxin to high-affinity receptor sites followed by a rapid 


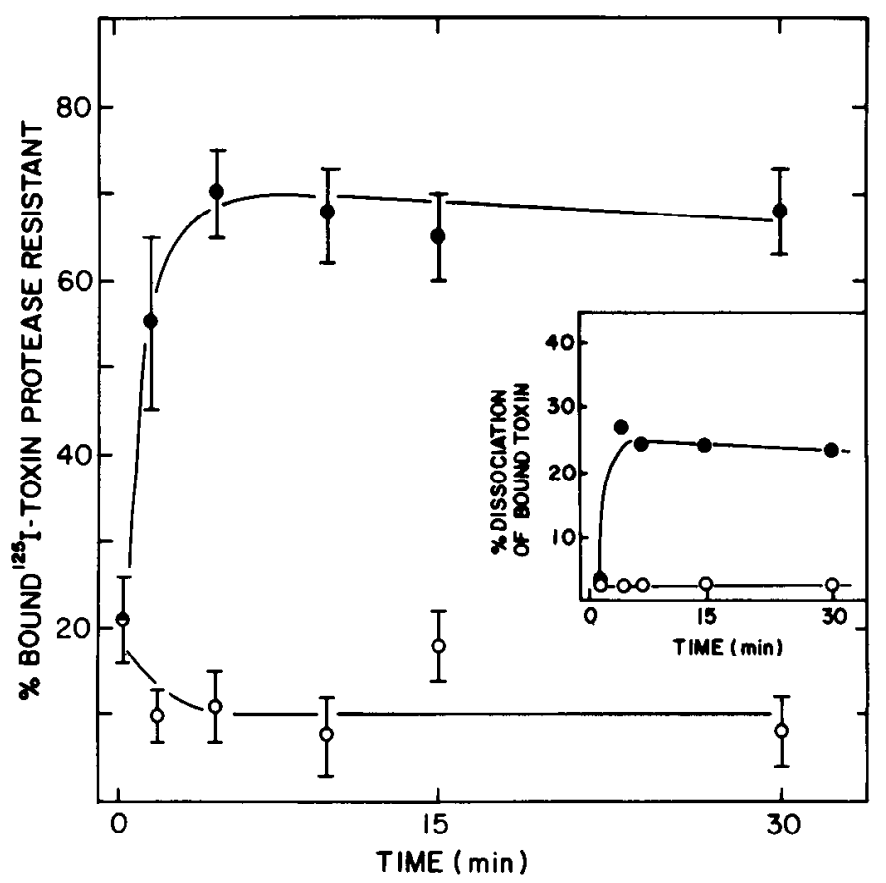

Figure 5. Kinetics of ${ }^{25} \mathbf{I}$-tetanus toxin internalization. N18-RE-105 cells $\left(5 \times 10^{5}\right.$ cells attached to $35 \mathrm{~mm}$ dishes, $500 \mu \mathrm{g}$ cell protein) were incubated with $0.8 \mathrm{nM}^{125}$ I-tetanus toxin in $2 \mathrm{ml}$ of incubation buffer for $10 \mathrm{~min}$ at $0^{\circ} \mathrm{C}$. At the end of this time, the dishes were rinsed with $2 \mathrm{ml}$ of ice-cold rinse buffer and then $2 \mathrm{ml}$ of rinse buffer at $0^{\circ} \mathrm{C}$ was added to each dish. The dishes were either rapidly warmed up to $37^{\circ} \mathrm{C}$ (C) or were maintained at $0^{\circ} \mathrm{C}(\mathrm{O})$. (This is the zero-time value on the figure.) The cells were incubated for the indicated time periods and then exposed to pronase as described under Materials and Methods. Each data point is expressed as the percentage of bound toxin that is resistant to pronase digestion relative to controls treated in an identical manner except that pronase was not added. Therefore, the $37^{\circ} \mathrm{C}$ data are corrected for dissociation that occurs during the incubations. Each point is the mean $( \pm \mathrm{SE})$ from three separate experiments. Inset, Amount of bound toxin that dissociated during the incubations at $0^{\circ} \mathrm{C}(\mathrm{O})$ and $37^{\circ} \mathrm{C}$ $(\bullet)$ relative to the values of bound 125 I-toxin at time zero.

receptor-mediated internalization. Further results reported here demonstrate that this specific internalization of toxin is dependent on temperature and intracellular ATP.

Several reports document that tetanus toxin specifically binds to receptors on purified neural membranes, synaptosomes, nervous tissue slices, and primary neurons in culture (Habermann, 1973; Lee et al., 1979; Rogers and Snyder, 1981; Yavin et al., 1981). The identification of neuronal cell lines that interact with tetanus toxin would be extremely valuable in the characterization of this toxin's molecular mechanism of action. Unfortunately, most transformed cell lines do not have the capacity to bind the toxin (Dimpfel et al., 1977; Mirsky et al., 1978; Yavin, 1984). Yavin and Habig (1984) have reported that a somaticneural hybrid line, NCB-20, binds more ${ }^{125}$ I-labeled tetanus toxin than any other cell line so far examined. However, the receptor level is about sevenfold lower than that found on primary neurons in culture, and these cells have some toxin-binding properties at variance with those found on brain tissue. Two striking features regarding the N18-RE-105 cell line are that (1) these cells express a receptor density that is sixfold higher than the NCB-20 cells (crude microsomal membranes prepared from the N18-RE-105 cells have only a 2.6-fold less binding capacity than synaptic membrane preparations); and (2) unlike NCB-20 cells, the high-affinity receptors are very similar to those reported on brain membranes.

In order to understand the internalization process in intact cells, it is essential to have detailed quantitative information on

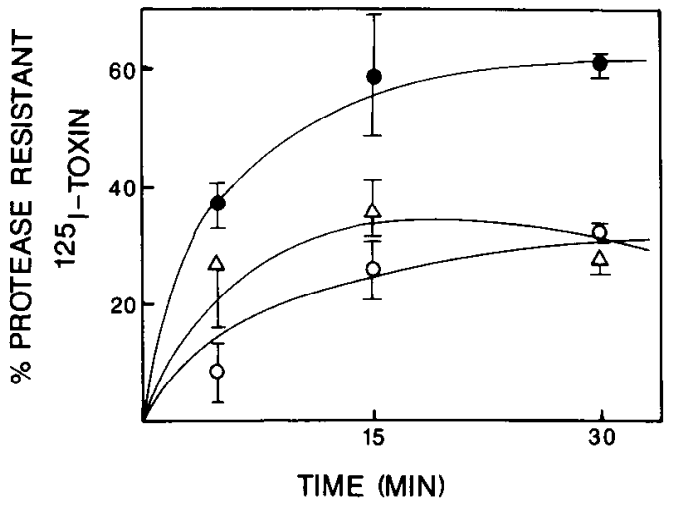

Figure 6. Effect of metabolic inhibitors on ${ }^{125} \mathrm{I}$-tetanus toxin internalization. N 18 -RE- 105 cells $\left(5 \times 10^{5}\right.$ cells plated onto $35 \mathrm{~mm}$ dishes, 500 $\mu \mathrm{g}$ cell protein) were preincubated for $1 \mathrm{hr}$ in incubation buffer $(2 \mathrm{ml})$ at either $0^{\circ} \mathrm{C}(0)$ or $37^{\circ} \mathrm{C}(\bullet)$. A third set of dishes was incubated for 1 $\mathrm{hr}$ at $37^{\circ} \mathrm{C}$ in $0.4 \mathrm{~nm}$ rotenone and $0.4 \mathrm{ng} / \mathrm{ml}$ oligomycin $(\Delta)$. After a 1 $\mathrm{hr}$ preincubation, ${ }^{125} \mathrm{I}$-tetanus toxin was added $(0.4 \mathrm{~nm})$, and the cells were incubated for the timcs indicated. The cells were then rinsed and incubated with pronase as described in detail in Materials and Methods. Each point is expressed as a percentage of control values, which represent ${ }^{125}$ I-toxin bound to cells not treated with pronase. The data points are the means of three experiments $( \pm S E)$, each performed in duplicate.

the receptor sites in these cells. Accordingly, studies were performed that showed that tetanus toxin receptors on this transformed cell line are closely related to those found on normal brain tissue. Thus, in agreement with previous studies of mammalian brain membranes and primary cultured neurons (Lee et al., 1979; Rogers and Snyder, 1981; Yavin et al., 1981), ${ }^{125}$ Itetanus toxin binding was regulated by increasing ionic strength, $\mathrm{pH}$, and temperature of the incubation medium. Moreover, ${ }^{125} \mathrm{I}$ tetanus toxin binding to N18-RE-105 cells was inhibited by unlabeled toxin, antitoxin, and gangliosides but not by tetanus toxoid (Table 1). The radioactive material that was bound to cells at $0^{\circ} \mathrm{C}$ appeared to be authentic toxin. Competition binding experiments revealed that tetanus toxin bound to a single class of high-affinity receptor sites on broken cell membrane preparations. The binding affinity of ${ }^{125}$ I-toxin for N18-RE-105 membranes was nearly as high as that observed for rat SPM, which was measured simultaneously in these studies (Fig. 3). Bioassays showed that the radiolabel that was bound by N18-RE-105 cells and then recovered was at least as toxic to mice as native solutions of ${ }^{125}$ I-labeled tetanus toxin. This is an important point since it is well known that preparations of ${ }^{125}$ I-labeled tetanus toxin contain 20-35\% radiolabeled, biologically inactive toxoid materials (Lee et al., 1979; Rogers and Snyder, 1981). These results support the conclusion that the N18-RE-105 cells express a physiologically relevant tetanus toxin binding determinant.

Previously published data indicate that complex gangliosides, notably $\mathrm{GD}_{\mathrm{lb}}$ and $\mathrm{GT}_{\mathrm{lb}}$, may act as receptors for tetanus toxin (Holmgren et al., 1980; Rogers and Snyder, 1981). Since previously published studies on neuroblastoma gangliosides have only reported the presence of mono- and disialogangliosides (Kebel et al., 1980), gangliosides that are much less potent in binding tetanus toxin (Holmgren et al., 1980), and since most neuronal cell lines do not bind significant amounts of tetanus toxin, we analyzed the ganglioside composition of the N18-RE105 cell line. Initial examination showed that the cells contain gangliosides that cochromatograph with bovine mono-, di-, and trisialoganglioside species (Fig. 1). Some of these species appear as doublets, such as the gangliosides that cochromatograph with $\mathrm{GM}_{2}$ and $\mathrm{GD}_{1 \mathrm{a}}$. This is a common occurrence in neuronal cell lines (Dahms and Schnaar, 1983) and has been attributed to differences in the ceramide portion of the molecules (Walton and Schnaar, unpublished observations). Ganglioside doublets 
with mobilities similar to those of $G_{1 a}$ and $G T_{1 b}$ were purified and subjected to partial acid hydrolysis since each ganglioside species has a distinct partial hydrolysis pattern that can be used for its identification. The patterns yielded by these two gangliosides are consistent with their designation as $\mathrm{GD}_{1 \mathrm{a}}$ and $\mathrm{GT}_{1 \mathrm{~b}}$ (Fig. 2). Thus, the N18-RE-105 cell line not only contains the ganglioside $\left(\mathrm{GT}_{\mathrm{Ib}}\right)$ thought to be a potent tetanus toxin receptor (Holmgren et al., 1980), but also is one of the few neuronal cell lines whose ganglioside species are similar to those found in mammalian brain.

Although the N18-RE-105 tetanus toxin receptor has been extensively characterized in this report, the major goal of these studies was to provide insight into the events that occur after initial receptor occupancy. The lack of saturability of ${ }^{12 s} I$-toxin binding to intact cells at $37^{\circ} \mathrm{C}$, in the absence of any detectable ligand degradation, strongly suggested that internalization of the toxin occurred. In order to investigate this possibility, a technique was developed that effectively differentiates between surface-bound toxin and toxin that has been translocated from the surface. This method exploits the susceptibility of surface-bound toxin to pronase digestion and is analogous to methods from previous reports on the release of surface-bound epidermal growth factor and diphtheria toxin by proteolytic treatment (Aharonov et al., 1978; Dorland et al., 1978). The pronaseresistant radiolabel has been defined operationally as internalized toxin, although it is clear that these experiments cannot distinguish between toxin that is actually internalized and toxin that is sequestered in some other manner. Further studies are needed to explore these possibilities.

This pronase-digestion assay has been valuable in defining characteristics of a tetanus toxin internalization process. First, intact cells are required; ${ }^{125}$ I-labeled toxin remains on the surface of broken cell membrane preparations (Table 2). Second, toxin internalization is dependent on temperature; little internalization of toxin was observed at $0^{\circ} \mathrm{C}$, while as much as $80 \%$ of the surface-bound toxin was internalized at $37^{\circ} \mathrm{C}$ (Table 2). Moreover, temperature pulse studies indicated that the internalization of surface-bound toxin was quite rapid with a half-life of $5 \mathrm{~min}$ at $37^{\circ} \mathrm{C}$ (Figs. 4,5 ). Finally, the rapid uptake mechanism is dependent on intracellular ATP. When ATP levels were decreased by $95 \%$ by metabolic inhibitors, tetanus toxin uptake levels were reduced to $0^{\circ} \mathrm{C}$ values (Fig. 6).

It is important to know if the internalization process described here is related to tetanus toxin's mechanism of action in vivo. The best demonstration of this correlation would be to show a direct relationship between toxin internalization and an appropriate functional response; that is, in this case, the inhibition of neurotransmitter release. Direct functional studies with the N18RE- 105 cells have not bcen performed since it has not yet been possible to identify their neurotransmitter characteristics (Malouf et al., 1984a).

Despite this limitation, the high-affinity binding-internalization process that has been quantitated in this report is complementary to and expands on the results of previous studies with analogous systems. Several reports have provided qualitative evidence that primary cultured neurons appear to internalize tetanus toxin in a temperature-dependent manner (Yavin et al., 1981, 1983). Schmitt et al. (1981) have postulated that a temperature-mediated internalization step precedes tetanus toxininduced blockade of neurotransmission in isolated neuromuscular junctions. Second, there is some evidence that the uptake of Clostridial neurotoxins can be rapid. A rapid internalization (on the order of minutes) of tetanus into primary cultures of spinal cord neurons has been recently observed (Critchley et al., 1985). However, because of the relatively high concentrations of tetanus toxin used in these experiments $(66 \mathrm{nM})$, it is not clear if high-affinity receptors mediate this process. Botulinum toxin becomes inaccessible to antitoxin in neuromuscular junc- tions with a half-time of 5 min (Simpson, 1980). Finally, Dolly et al. (1984) used autoradiographic methods to show qualitatively that metabolic inhibitors prevented the uptake of botulinum toxin into intact neuromuscular junctions. All of these observations can be explained by the mechanisms characterized in this report. Taken together, these results document the relevance of the toxin-entry process identified on N18-RE-105 cells.

This study establishes that N18-RE-105 cells are a valuable system for studying tetanus toxin's mechanism of action. Experiments are now in progress to study in more detail the uptake process and the subcellular localization of internalized toxin.

\section{References}

Aharonov, A., R. M. Pruss, and H. R. Herschman (1978) Epidermal growth factor, the relationship between receptor regulation and mitogenesis. J. Biol. Chem. 253: 3970-3977.

Bergey, G. K., R. L. Macdonald, W. H. Habig, M. C. Hardegree, and P. G. Nelson (1983) Tetanus toxin: Convulsant action on mouse spinal cord neurons in culture. J. Neurosci. 3: 2310-2323.

Bolton, A. E., and W. M. Hunter (1973) The labelling of proteins to high specific radioactivities by conjugation to a ${ }^{125}$ I-containing acylating agent. J. Biochem. 133: 529-539.

Bradford, M. (1976) A rapid and sensitive method for the quantitation of microgram quantities of protein utilizing the principle of dye binding. Anal. Biochem. 72: 248-254.

Collingridge, G. L., G. G. S. Collins, J. Davies, T. A. James, M. J. Neal, and $P$. Tongroach (1980) Effect of tetanus toxin on transmitter release from the substantia nigra and striatum in vitro. J. Neurochem. 34: 540-547.

Critchley, D. R., P. G. Nelson, W. H. Habig, and P. H. Fishman (1985) Fate of tetanus toxin bound to the surface of primary neurons in culture: Evidence for rapid internalization. J. Cell Biol. 100: 14991507.

Curtis, D. R., and W. C. DeGroat (1968) Tetanus toxin and spinal inhibition. Brain Res. 10: 208-212.

Dahms, N. M., and R. L. Schnaar (1983) Ganglioside composition is regulated during differentiation in the neuroblastoma $\times$ glioma hybrid cell line NG108-15. J. Neurosci. 3: 806-817.

Davies, J., and R. Tongroach (1979) Tetanus toxin and synaptic inhibition in the substantia nigra and striatum of the rat. J. Physiol. (Lond.) 290: 23-36.

Dimpfel, W., R. T. C. Huang, and E. Habermann (1977) Gangliosides in nervous tissue cultures and binding of ${ }^{125}$ I-labelled tetanus toxin, a neuronal marker. J. Neurochem. 29: 329-334.

Dolly, J. O., J. Black, R. S. Williams, and J. Melling (1984) Acceptors for botulinum neurotoxin reside on motor nerve terminals and mediate its internalization. Nature 307: 457-460.

Dorland, R. B., J. L. Middlebrook, and S. H. Leppla (1979) Receptormediated internalization and degradation of diphtheria toxin by monkey kidney cells. J. Biol. Chem. 254: 11337-11342.

Fredman, P. (1980) Isolation and separation of gangliosides on a new form of glass bead ion exchanger. In Structure and Function of Gangliosides, L. Svennerholm, P. Mandel, H. Dreyfus, and P. F. Urgan, eds., pp. 23-31, Plenum, New York.

Goldberg, R. L., T. Costa, W. H. Habig, L. D. Kohn, and M. C. Hardegree (1981) Characterization of fragment $\mathrm{C}$ and tetanus toxin binding to rat brain membranes. Mol. Pharmacol. 20: 565-570.

Habermann, E. (1973) Interaction of labelled tetanus toxin with substructures of rat brain and spinal cord in vitro. Naunyn Schmiedebergs Arch. Pharmacol. 276: 341-359.

Holmgren, J., H. Elwing, P. Fredman, and L. Svennerholm (1980) Polystyrene-adsorbed gangliosides for investigation of the structure of the tetanus toxin receptor. Eur. J. Biochem. 106: 371-379.

Laemmli, U. K. (1970) Cleavage of structural protein during assembly of the head of bacteriophage T4. Nature 227: 680-685.

Lee, G., E. F. Grollman, S. Dyer, F. Beguinot, and L. D. Kohn (1979) Tetanus toxin and thyrotropin interactions with rat brain membrane preparations. J. Biol. Chem. 254: 3826-3832.

Maiouf, A. T., R. L. Schnaar, and J. T. Coyle (1984a) Characterization of a glutamic acid neurotransmitter binding site on neuroblastoma hybrid cells. J. Biol. Chem. 259: 12756-12762.

Malouf, A. T., R. L. Schnaar, and J. T. Coyle (1984b) Agonists and 
cations regulate the glutamic acid receptors on intact neuroblastoma hybrid cells. J. Biol. Chem. 259: 12763-12768.

Mellanby, J. (1984) Comparative activities of tetanus and botulinum toxins. Neuroscience 11:29-34.

Mellanby, J., and J. Green (1981) How does tetanus toxin act? Neuroscience 6: 281-300.

Mirsky, R., L. M. B. Wendon, P. Black, C. Stolkin, and D. Bray (1978) Tetanus toxin: A cell surface marker for neurones in culture. Brain Res. 148: 251-259.

Price, D. L., J. Griffin, A. Young, K. Peck, and A. Stocks (1975) Tetanus toxin: Direct evidence for retrograde intra-axonal transport. Science 188: 945-947.

Rebel, G., J. Robert, and P. Mandel (1980) Glycolipids and cell differentiation. In Structure and Function of Gangliosides, L. Svennerholm, P. Mandel, H. Dreyfus, and P. F. Urban, eds., pp. 159-166, Plenum, New York.

Rogers, T. B. (1983) Binding of ${ }^{125}$ I-tetanus toxin to neuronal cell lines in culture. Abstr. Soc. Neurosci. 9: 348.

Rogers, T. B., and S. H. Snyder (1981) High affinity binding of tetanus toxin to mammalian brain membranes. J. Biol. Chem. 256: 24022407.

Schmitt, A., F. Dreyer, and C. John (1981) At least three sequential steps are involved in the tetanus toxin-induced block of neuromuscular transmission. Naunyn Schmiedebergs Arch. Pharmacol. 317. 326-330.

Schnaar, R. L., and A. E. Schaffner (1981) Separation of cell types from embryonic chicken and rat spinal cord: Characterization of motoneuron-enriched fractions. J. Neurosci. $1:$ 204-217.

Schwab, M. E., K. Suda, and H. Thoenen (1979) Selective retrograde transsynaptic transfer of a protein, tetanus toxin, subsequent to its retrograde axonal transport. J. Cell Biol. 82: 798-810.

Simpson, L. L. (1980) Kinetic studies on the interaction between botulinum toxin type $A$ and the cholinergic neuromuscular junction. J. Pharmacol. Exp. Ther. 212: 16-21.

Stanley, P. E., and S. G. Williams (1969) Use of the liquid scintillation spectrometer for determining adenosine triphosphate by the luciferase enzyme. Anal. Biochem. 29:381-392.

Staub, G. C., T. Nichols, R. Baichwal, and T. B. Rogers (1984) Binding of ${ }^{125}$ I-tetanus toxin to neuronal cell lines in culture: Evidence for internalization of toxin. Abstr. Soc. Neurosci. 10:36.

Stoeckel, K., M. E. Schwab, and H. Thoenen (1977) Role of gangliosides in the uptake and retrograde axonal transport of cholera and tetanus toxin as compared to nerve growth factor and wheat germ agglutinin. Brain Res. 132: 273-285.

Wellhoner, H. H. (1982) Tetanus neurotoxin. Rev. Physiol. Biochem. Pharmacol. 93: 1-68.

Yavin, E. (1984) Gangliosides mediate association of tetanus toxin with neural cells in culture. Arch. Biochem. Biophys. 230: 129-137.

Yavin, E., and W. H. Habig (1984) Binding of tetanus toxin to somatic neural hybrid cells with varying ganglioside composition. J. Neurochem. 42: 1313-1320.

Yavin, E., Z. Yavin, W. H. Habig, M. C. Hardegree, and L. D. Kohn (1981) Tetanus toxin association with developing neuronal cell cultures. J. Biol. Chem. 256: 7014-7022.

Yavin, E., Z. Yavin, and L. D. Kohn (1983) Temperature-mediated interaction of tetanus toxin with cerebral neuron cultures: Characterization of a neuraminidase-insensitive toxin-receptor complex. J. Neurochem. 40: 1212-1219. 